\title{
Spatiotemporal Spectral Variations of AOT in India's EEZ over Arabian Sea: Validation of OCM-II
}

\author{
C. P. Simha, ${ }^{1}$ P. C. S. Devara, ${ }^{1}$ S. K. Saha, ${ }^{1}$ K. N. Babu, ${ }^{2}$ and A. K. Shukla ${ }^{2}$ \\ ${ }^{1}$ Physical Meteorology and Aerology Division, Indian Institute of Tropical Meteorology, Dr. Homi Bhabha Road, \\ Pashan, Pune 411 008, India \\ ${ }^{2}$ DPD, Oceansat-II UP (OCM2 Validation), Space Applications Centre, ISRO, Ahmedabad 380 015, India
}

Correspondence should be addressed to P.C.S. Devara, devara@tropmet.res.in

Received 1 May 2012; Revised 12 July 2012; Accepted 18 August 2012

Academic Editor: Swadhin Behera

Copyright () 2012 C. P. Simha et al. This is an open access article distributed under the Creative Commons Attribution License, which permits unrestricted use, distribution, and reproduction in any medium, provided the original work is properly cited.

\begin{abstract}
We report the results of sun-photometric measurements of Aerosol Optical Thickness (AOT) in India's Exclusive Economic Zone (EEZ) over the Arabian Sea along with synchronous Ocean Color Monitor (OCM-II) derived AOT estimates during December 12, 2009-January 10, 2010. Relatively higher values of Angstrom exponent $(\alpha)$ around 1.2 near coast and 0.2-0.8 in the India's EEZ, observed during the cruise period, indicate the presence of smaller particles near the coast due to anthropogenic activities; and larger particles in the India's EEZ due to advection of pollutants from Indian subcontinent via long-range transport. Results related to $\alpha$ and its derivative reveal four different aerosol types (urban-industrial, desert-dust, clean-marine, and mixed-type) with varying fraction during the study period. Surface radiative forcing due to aerosols is found to be $20 \mathrm{~W} / \mathrm{m}^{2}$ over India's EEZ. OCMderived AOTs showed good corroboration with in situ measurements with a correlation coefficient of about 0.95. A reasonably good correlation was also observed between AOT and wind speed $(R=0.6)$; AOT and relative humidity $(R=0.58)$. The concurrent MODIS AOT data also agree well with those observed by the OCEANSAT (OCM-II) satellite during the campaign period.
\end{abstract}

\section{Introduction}

Although aerosols are minute particles, their cumulative radiative effect (both direct and indirect) on the atmosphere is tremendous [1]. They can scatter away and absorb the incident solar radiation leading to cooling of the earth's surface and simultaneous warming of the lower atmosphere up to about $6 \mathrm{~km}[2,3]$. Aerosols also pollute the atmosphere and reduce visibility [4]. Continental aerosols are mainly windblown mineral dust and carbonaceous and sulphate particles produced by forest fires, land-use, and industrial activities, while marine aerosols are mainly sea-salt particles are produced by wave-breaking, and sulphate particles produced by the oxidation of Dimethyl Sulphide (DMS), released by the phytoplankton [5]. As the oceans cover more than 70\% of the earth's surface, they are one of the largest sources of natural aerosols. Being hygroscopic, marine aerosols are crucial in cloud formation in the marine boundary layer and are also important in the radiative coupling between the ocean and the atmosphere. While continental aerosols can be both scattering and absorbing, marine aerosols are mostly of scattering type [6], thus becoming a decisive factor in the albedo of the earth [7-10]. Aerosols are poorly characterized in climate models due to the lack of global information on their physico-chemical properties and spatial and temporal distributions $[10,11]$.

Most of the in situ data campaigns for aerosol characterization have provided significant information on spectral variability, aerosol type, particle size, and so forth; however, they could not provide information on the spatial distribution and transport process. Routine monitoring of aerosol events and their subsequent dispersal pattern are important in order to understand their role in the climatic processes. The satellite sensors provide platform for making observations covering large area as also their short-term and frequent repeatability. Ocean-color sensors for example, CZCS, SeaWiFS, MODIS, POLDER, OCEANSAT-I, OCEANSAT-II have been used to study aerosols, apart from being used to study the ocean color $[3,4]$. Most of the ocean-color sensors are equipped with a few additional near 
infrared (NIR) bands $(\lambda>700 \mathrm{~nm})$, which are helpful in providing vital information on atmospheric aerosols due to strong absorption by water in the NIR wavelengths. OCEANSAT-II Ocean Color Monitor (OCM-II) is one such satellite providing ocean color measurements around the sea adjoining the Indian subcontinent. Das and Mohan [4] have shown the use of OCM data for the estimation of AOT and its spatial and temporal behavior over the Indian Ocean region.

The present study focuses primarily on the temporal, spatial, and spectral variations of marine AOT over the India's EEZ (Arabian Sea) in detail. This study is performed based on the measurements conducted on-board a research vessel Sagar Kanya and OCEANSAT-II (OCM-II) sensorderived AOTs during December 12, 2009-January 10, 2010 in the India's EEZ (Arabian Sea). During the months of December through February, north-easterly winds over the Indian subcontinent carry aerosols from the land towards the oceanic atmosphere. These months, therefore, become the most ideal period to study the effect of continental aerosols and their dispersal in the oceanic atmosphere. The satellitederived AOT values have been compared with the in situ measurements, and long-range transport of air mass from the Indian subcontinent is also examined with the HYSPLIT back trajectories during the cruise period.

\section{Instrumentation and Calibration}

A total of four instruments were used concurrently in the present OCM-II calibration and validation experiment. They are (i) Microtops sun-photometer that measures AOT; (ii) Microtops ozonometer that measures precipitable water content (PWC) and total column ozone (TCO); (iii) Thermohygrometer/AWS (Automated Weather Station) which makes measurements of surface-level meteorological parameters; (iv) a short-wave (SW) pyranometer that determines downwelling solar radiation. Calibration is essential for these instruments to ensure reliability of its products [12]. All the above-mentioned instruments were calibrated before their deployment. The Microtops provides good quality measurements on moving platforms as explained in the sections to follow. The calibration of this instrument is done at Mauna Loa, Hawaii, a unique high-altitude location allowing access to a pure and stable atmosphere. The manufacturer, $\mathrm{M} / \mathrm{s}$ Solar Light, Philadelphia, USA, undertakes this calibration campaign each year. The calibration relies on a highperformance voltage reference with the temperature coefficient $\leq 0.001 \%$ per degree Celsius and long-term stability of $\sim 0.005 \%$ per year. The full width at half maximum bandwidth at each of its wavelength channels is $2.4 \pm 0.4 \mathrm{~nm}$, and the accuracy of the sun-targeting angle is better than $0.1^{\circ}$. Additional details of the radiometers used in the present study have been published by [13-15].

\section{Site Location and Measurements Methodology}

3.1. SK-266 ORV Sagar Kanya Cruise Observations. India, traditionally a seafaring country [16], has a wide India's EEZ (Exclusive Economic Zone) of about 2 million sq. km. all along the $7500 \mathrm{~km}$ long coastline around her. The living and nonliving resources in this zone constitute around two-thirds of the landmass of the country. Additionally, several million people, living along the coastline, are directly influenced by the oceanography of the India's EEZ, coastal environmental hazards, and related social issues. The India's EEZ also composed of many economically exploitable mineral and hydrocarbon resources. Transportation, defense, and fishing are traditional uses of the ocean. But increasing demand for fuels, metals, and construction materials has, in many instances, outstripped the production capabilities of land resources and increasingly the ocean is being exploited to meet the need. This has been particularly obvious in the case of petroleum and natural gas, for which the India's EEZ is expected to become a prime source in the next few decades. The in situ Aerosol Optical Thickness (AOT) and other observations were collected on-board ORV Sagar Kanya cruise (SK-266), during December 12, 2009-January 10, 2010. Figure 1 displays the cruise track covered in the India's EEZ (Arabian Sea). The ship commenced from Goa, moved towards south westwards in the ocean away from the coast and reached the India's EEZ (200 nautical miles from the sea shore, that is, $13^{\circ} \mathrm{N}, 68^{\circ} \mathrm{E}$ ) and covered line-by-line (around 36 multiple paths during the study period), then it returned from India's EEZ $\left(13^{\circ} \mathrm{N}, 70.5^{\circ} \mathrm{E}\right)$ to the Goa port.

Microtops measures AOT at six wavelengths, each centered at 380,440,500, 675, 870, and $1020 \mathrm{~nm}$, from the instantaneous solar flux measurements using its internal calibration. The on-board measurements were carried out following the standard AOT measurements protocol for shipborne surveys. The measurement protocol was to make a triplet of observations every 5-10 minutes, while following the suggestions of the previous literature [17-19], when the solar disk was free from clouds. Also, the sun-photometer and ozonometer were switched on and off routinely to update the temperature correction [17]. The collected data were processed and grouped into series by adhering to the methodology of Smirnov et al. [19]. The arithmetic and geometric daily averages of AOT, compared to avoid sampling biases [20], agree within 0.007 or less. During the cruise, the sun-photometer and ozonometer were operated from 08:00 hrs to $16: 00 \mathrm{hrs}$ at 5 -minute interval in the sunrise and sunset time, and in the remaining period 10-minute interval. AOT measurements were made from the ship-deck. Simultaneous surface-level meteorological observations like atmospheric pressure, wind speed/direction, temperature and relative humidity, and so forth were recorded by the AWS (Model WDL 1002; Dynalab, Pune, India). The concurrent down-welling surface SW radiation data were archived at a 1minute interval using the gimbal-mounted SW pyranometer (Model DWR 8101; Weathertech Pvt. Ltd., Pune, India). The directional and nonlinearity errors for the pyranometer are estimated to be about $2 \%$ of the reading, whereas total daily expected uncertainty is $\pm 3 \%$. OCM-II satellite data was obtained corresponding to the in situ data collected in the Arabian Sea during December 12, 2009-January 10, 2010 covering the study area for every alternate day, because the OCM-II has once-in-two-days repeatability. OCM records reflected radiation from earth's surface in eight spectral 


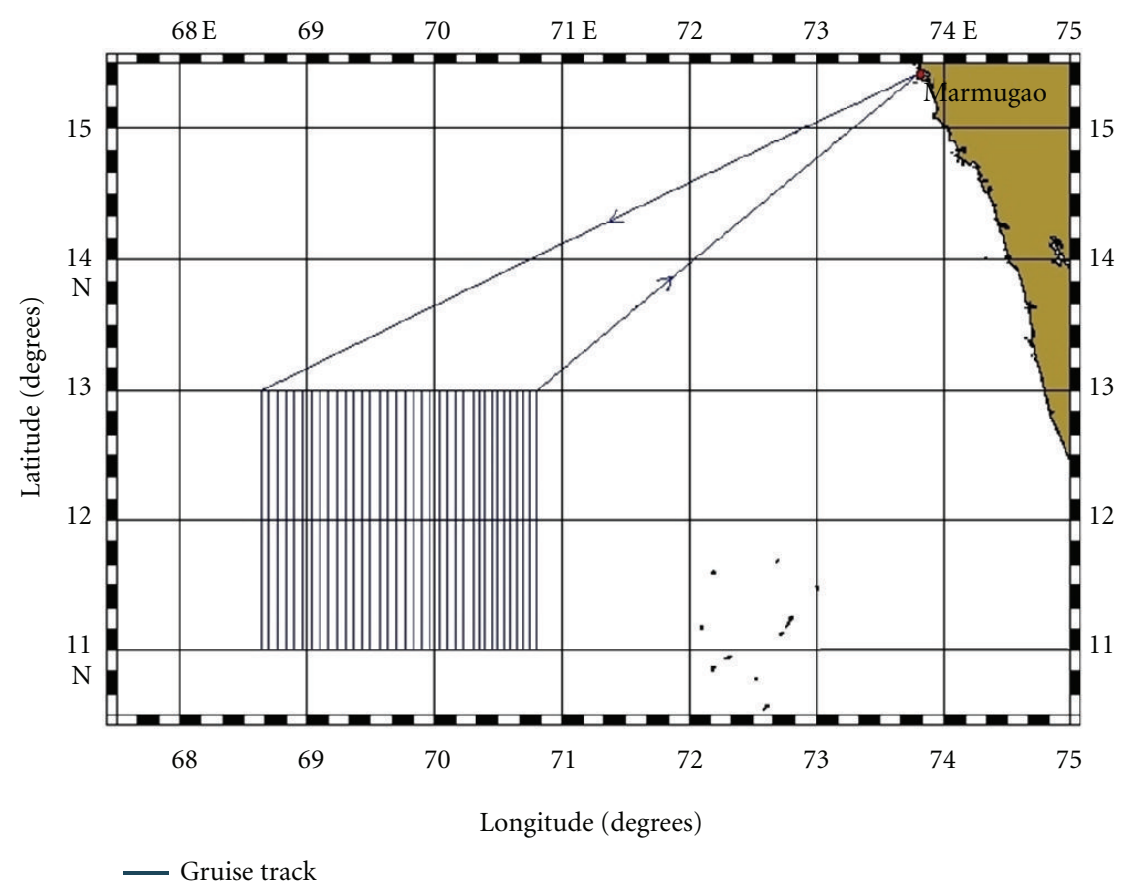

FIGURE 1: SK-266 cruise track in the India's EEZ.

bands ranging within the $412-865 \mathrm{~nm}$ wavelength bands. The NIR wavelength band of $865 \mathrm{~nm}$ has been used for the estimation of AOT over the oceanic surface.

\section{Results and Discussion}

4.1. Spectral AOT Variations. The spectral variations of AOT at six wavelengths for the entire cruise period are shown in Figure 2. The daily mean AOT values at $500 \mathrm{~nm}$ wavelength for 30 days of observations were mostly in the range from 0.14 to 0.7 . Unusual AOT values occurred during the cruise period due to a sudden low-pressure system that formed near the Sri Lankan region. We have categorized the measurements into coastal and India's EEZ based on the distance from the coast. This division is arbitrary, but sufficient to illustrate the differences between the aerosol spectral properties close to and far from land. The AOT data collected from December 15, 2009-January 8, 2010 represent mainly India's EEZ environment and remaining data were considered for coastal environment. It is noted that AOT at $500 \mathrm{~nm}$ was about 0.23 over the India's EEZ away from the coast, similar variations have been reported by Chauhan et al. [21] and Kalapureddy and Devara [22]. When the ship approached the coast, the mean AOT at $500 \mathrm{~nm}$ has increased to 0.45 while the values of AOT decreased as the ship moved away from the coast in the India's EEZ, thereafter it increased again as the ship approached the coast. Figure 2 shows lower values of spectral variations in the India's EEZ in the Arabian Sea from coast as compared to that of near-coast stations, which clearly reveal distinct information on particle size distribution over the two regions. The size of marine aerosol is found larger as compared to continental aerosols.

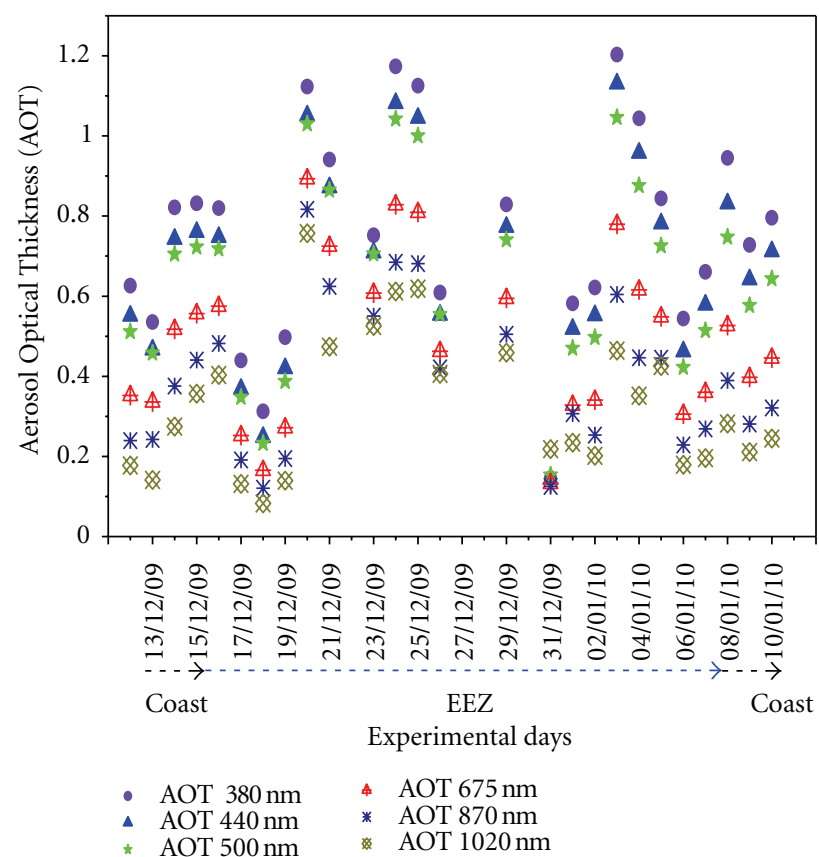

FIGURE 2: Spectral variation of the daily averages of in situ AOT for the cruise dates.

4.2. Ozone and PWC Variations. The daily mean columnar ozone variations are depicted in Figure 3. The TCO is found to vary from 210 to $255 \mathrm{DU}$. During the entire campaign, lower values of TCO were observed on two days, which are considered to be due to photochemical reactions with 


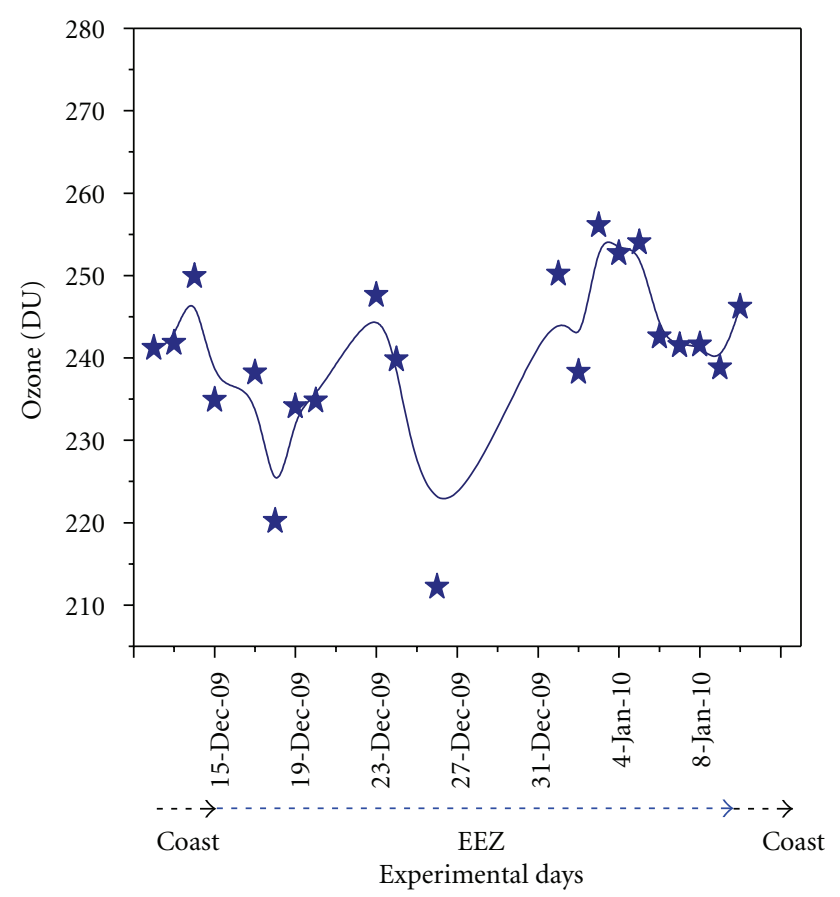

Figure 3: Same as Figure 2 but for ozone.

$\mathrm{NO}_{\mathrm{x}}$ and CO. The PWC variations are shown plotted in Figure 4. The PWC values range from 1.5 to $3.8 \mathrm{~cm}$. These values are found very low in the beginning of the campaign period due to the low pressure system on December 19, 2009, thereafter it suddenly increased to very high value $(\sim 3.0 \mathrm{~cm})$ and continued to be high up to 3 January 2010.

4.3. Angstrom Parameters. Spectral variation of AOT provides information on the particle size distribution in the total atmospheric column. The inverse power-law for spectral variation of $\mathrm{AOT}$ is given as

$$
\tau=\beta \lambda^{-\alpha},
$$

where, $\alpha, \beta$, and $\lambda$ represent the Angstrom exponent, turbidity factor, and wavelength used, respectively. The value of $\alpha$ depends on the portion of the concentration of large to small aerosol particles and is related in such a manner that higher value of $\alpha$ indicates dominance of smaller particles. $\beta$ represents the total aerosol loading in the atmosphere and as such higher values of $\beta$ give an indication of poor visibility due to higher turbidity level. The variations in Alpha and Beta during the cruise period are shown plotted in Figure 5. It is clear from the figure that mean value of $\alpha$ over the coastal region $(\sim 1.24)$ is found to be larger as compared to that over the open ocean, that is, India's EEZ $(\sim 0.2-0.8)$. Relatively larger values of $\beta$, found in the coastal water regions, indicate the presence of relatively higher concentration of particles as compared to the measurements over the open ocean (India's EEZ) waters. The larger values of Angstrom exponent $(\alpha)$ can also be attributed to the higher fine-mode aerosol loading close to the coast, arising mainly from the anthropogenic activities. The second derivative of

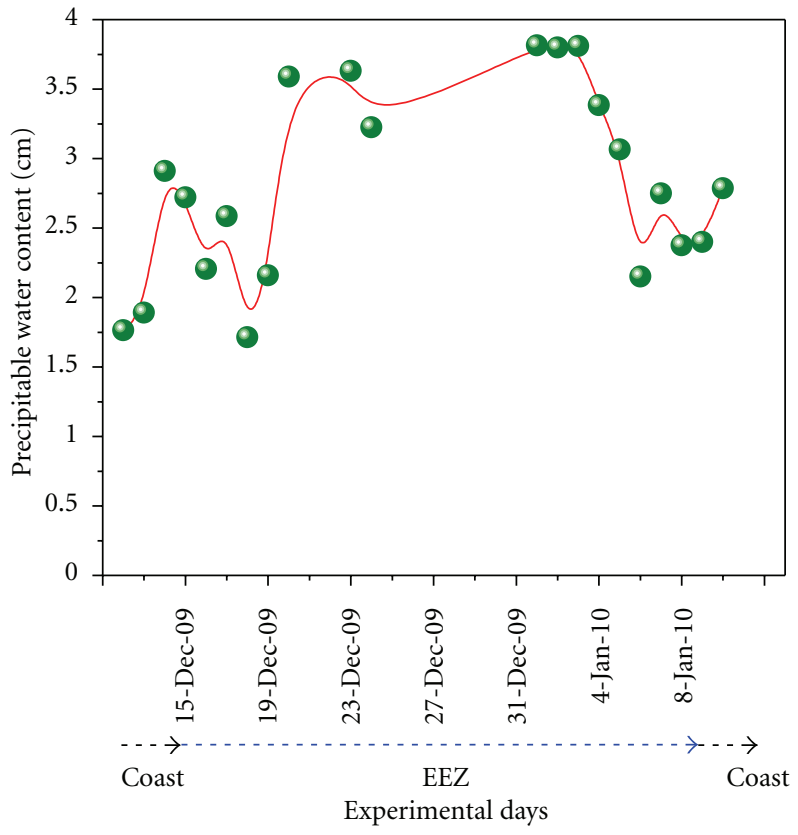

FIgURE 4: Same as Figure 2 but for precipitable water content.

Alpha constitutes a measure of the rate of change of the slope with respect to wavelength. Eck et al. [23] attempted to quantify the curvature of spectral variation of AOT using the second derivative of $\ln \tau_{\lambda}$ versus $\ln \lambda$, that is, derivative of $\alpha$ with respect to $\ln \lambda$ as

$$
\alpha^{\prime}=\frac{d(\alpha)}{d(\ln \lambda)} .
$$

The curvature can be an indicator of aerosol particle size, with negative curvature indicating aerosol particle size distribution dominated by fine-mode while positive curvature indicates size distribution with significant contribution by coarse-mode [23]. $\alpha^{\prime}$ close to zero indicates constant slope AOT, indicating coarse-mode dominance, while higher values represent rapidly changing the slope. In the present study, $\alpha^{\prime}$ was derived using observed AOT at $380,440,500,675$, 870 , and $1020 \mathrm{~nm}$ wavelengths. Both the coarse- and finemode aerosol size distributions had been clearly noticed from Figure 6. Near the coastal environment, as discussed above, the variations in AOT, Alpha, Beta indicated finemode particles (negative $\alpha^{\prime}$ value) which are considered to be due to anthropogenic activities. Once the ship entered the India's EEZ, coarse-mode particle dominance is observed (positive $\alpha^{\prime}$ value). These features have been substantiated through long-range transport of air mass trajectories around the India's EEZ by using NOAA HYSPLIT model.

4.4. Surface Radiative Forcing. The Pyranometer-measured global SW flux in the wavelength region between 0.3 and $3.0 \mu \mathrm{m}$ is correlated with instantaneous AOT $500 \mathrm{~nm}$ (corrected for the air mass factor, $1 / \mu$ ) so as to estimate the surface radiative forcing [24]. Normalization of AOT with $\mu(=\cos \theta)$ is found to be necessary as the slant air column 


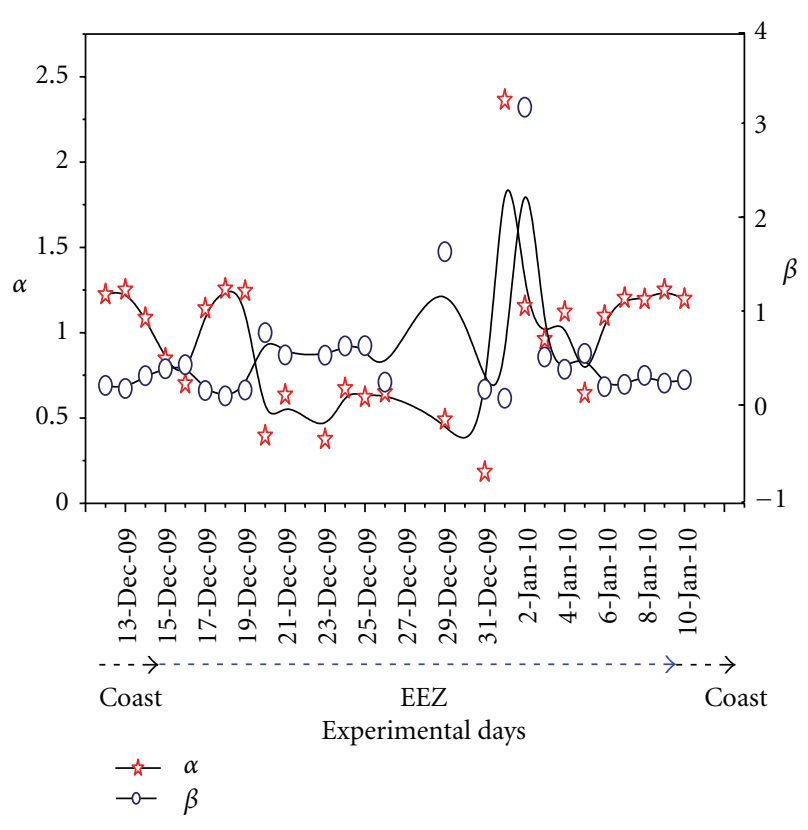

FIGURE 5: Alpha-beta variations during the cruise period.

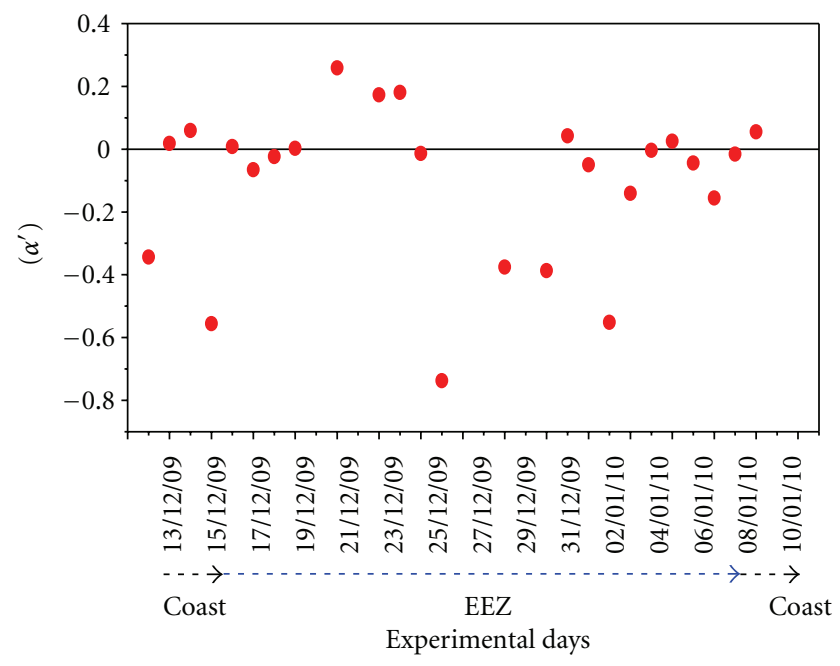

FIGURE 6: Alpha prime variations during SK-266 campaign.

length increases with increasing solar zenith angle $\theta$. The observed flux represents the solar flux at sea surface, normal to the angle of incidence, with a cone of about $2.5^{\circ}$ around the Sun. The AOT values for solar zenith angle greater than $60^{\circ}$ are excluded (to avoid Earth's curvature effect) and the AOT/ $\mu$ values are restricted to within 0.80 . Figure 7 shows scatter plot of the measured normalized SW flux with AOT for India's EEZ. A straight line could be fitted with a negative slope of about $20.08 \mathrm{~W} / \mathrm{m}^{2}$ for every 0.1 increase in the AOT (from Figure 7) for India's EEZ in the Arabian Sea. The scatter between the two data sets is considered mainly to be due to (i) uncertainties in global flux spatial inhomogeneity of the atmosphere within the hemisphere and (ii) contamination of the solar flux by broken and optically thin clouds. Moreover, such a relationship is consistent with

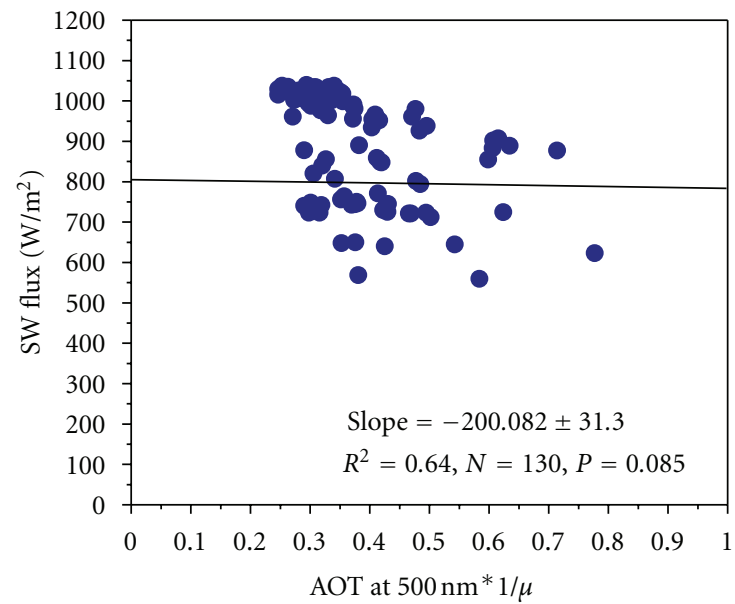

Figure 7: Association between the surface short-wave solar flux, and columnar AOT at $500 \mathrm{~nm}$ normalized for the air mass $(1 / \mu)$ over the India's EEZ.

the surface solar flux values reported by earlier researchers [24-27].

4.5. Validation of OCM-II with In Situ AOT at $865 \mathrm{~nm}$. The irradiance data in the HDF format from the OCM-II sensor were converted into the geophysical coordinate mode (latlong mode) using the ENVISAT-II software [4, 21]. Thus OCM-II data were obtained at a specific wavelength in the India's EEZ and matched with the observed Microtops data. The OCM-II satellite passes in the Arabian Sea were available at 12:30 PM on alternate days. Hence the ship data were recorded from 11:00 AM to $1: 30 \mathrm{PM}$ and is synchronized with particular lat-long of the ship at 12:30 PM. Here we considered the OCM-II data in the $5^{\circ} \times 5^{\circ}$ grid mode to obtain AOT. The OCM-II provides AOT at $865 \mathrm{~nm}$ while the Microtops yields AOT at $870 \mathrm{~nm}$. By using the Angstrom exponent formula, the AOTs at OCM-II and Microtops were matched at the wavelength of $865 \mathrm{~nm}$. OCM-II data for cruise duration of 12 December 2009 till 10 January 2010 for pass number 12 was processed by extracting average AOT at $865 \mathrm{~nm}$ values from AOT product using ENVISATII Software. A comparative analysis of the OCM-II derived $\mathrm{AOT}$ at $865 \mathrm{~nm}$ was done with in situ measured AOT values using the hand-held sun-photometer. Figure 8 shows the relationship between OCM-II derived and in situ measured AOT values at $865 \mathrm{~nm}$ for match-up locations. A total of six match-up locations could be achieved during the cruise duration, because of the day-by-day satellite passage of OCM-II sensor and sudden weather disturbance near the Sri Lankan region. It is evident from the figure that OCMII derived and in situ measured AOT values show a good correlation coefficient with less error $\left(R^{2}=0.95\right.$ and RMSE $=$ $10 \%)$. Most of the time OCM-II derived AOT is found to slightly over estimate the in-situ AOT.

4.6. Mapping of AOT over India's EEZ. The lat-long crosssection of AOT on different days over the India's EEZ during 


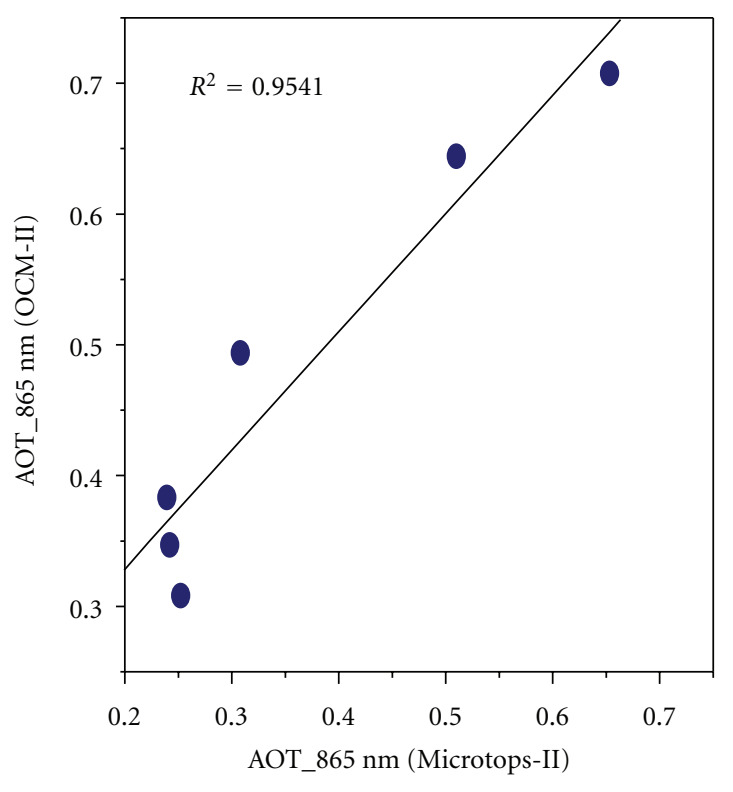

- AOT_865 nm (OCM-II)

(a)

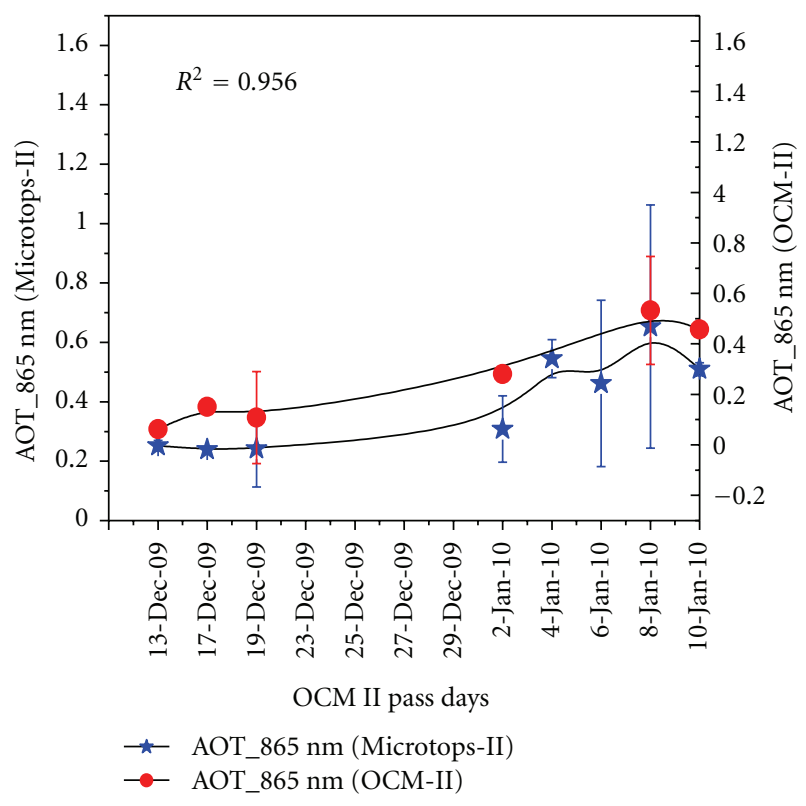

(b)

Figure 8: Comparison of Microtops Sun Photometer derived AOTs with OCEANSAT-II OCM-derived AOTs at 12:30 hrs (IST) during the cruise.

the cruise period is shown plotted in Figure 9. It is clear from the figure that near the coast line $\left(14.5^{\circ} \mathrm{N}, 72^{\circ} \mathrm{E}\right)$, AOT values are high. But when the ship enters the India's EEZ $\left(13^{\circ} \mathrm{N}, 71^{\circ} \mathrm{E}\right)$, they are very low. Due to sudden occurrence of weather disturbance over the observational site, AOT reached to very high. The lat-long cross-sections of TCO and PWC observed over the India's EEZ during the cruise period are depicted in Figures 10 and 11, respectively. It is evident that low ozone values were observed over the belt between $12^{\circ} \mathrm{N}$

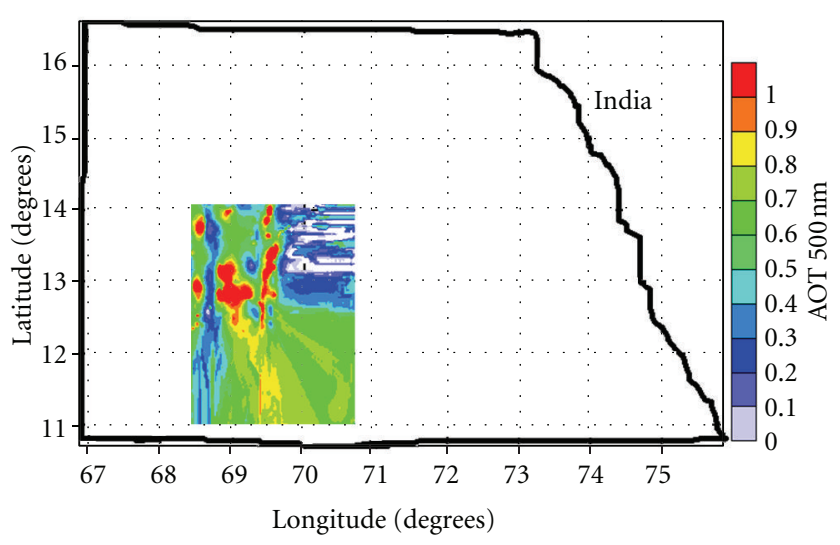

FIGURE 9: Lat-long cross-section of AOT over India's EEZ during 11 December-10 January 2010.

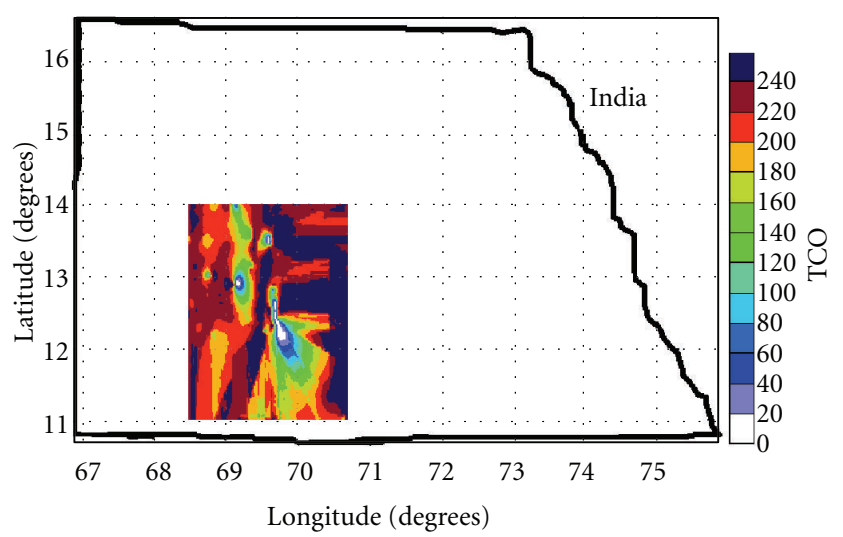

Figure 10: Lat-long cross-section of TCO over India's EEZ during 11 December-10 January 2010.

and $69^{\circ} \mathrm{E}$, which may be due to the transport of nitrogen compounds leading to ozone depletion. The higher PWC values noticed over the belt between $13^{\circ} \mathrm{N}$ and $69^{\circ} \mathrm{E}$ are considered to be due to sudden weather disturbance formed near the Sri Lankan region.

4.7. Long-Range Transport of Aerosols. Figure 12 portrays seven-day back trajectories (at three altitudes) for the entire India's EEZ as obtained from NOAA HYSPLIT model. They clearly reveal that different air masses (originating from Indian subcontinent, Sri Lanka, Arabian Sea) influenced the AOT over the experimental site (India's EEZ). This analysis also discloses that Arabian and Indian subcontinent air masses play a significant role in influencing the India's EEZ. It further reveals significant changes, which are considered to be due to observed day-to-day variability of aerosols properties. The lower altitude air masses originate from the Arabian Sea and Indian subcontinent without traveling longer distance while those at higher altitudes travel longer distance and effect significantly the long-range transport of air masses over the Sri Lankan region. 


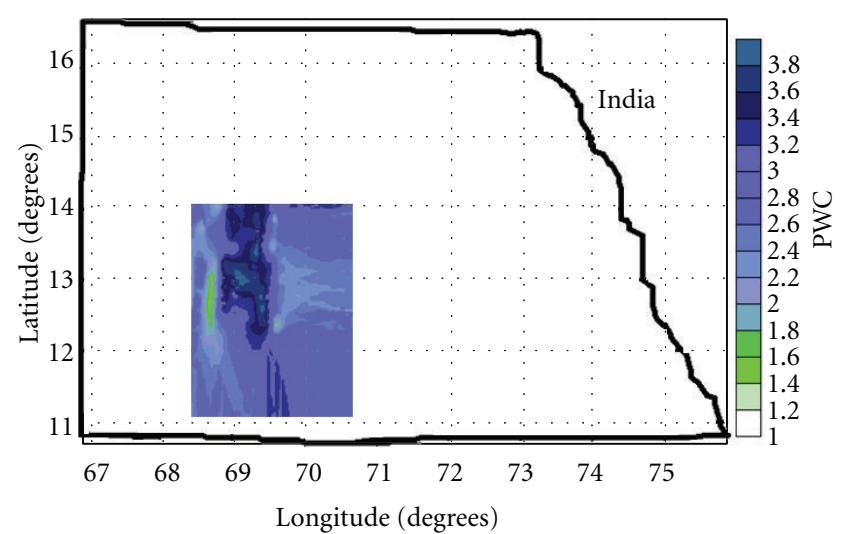

FIGURE 11: Lat-long cross-section of PWC over INDIA'S EEZ during 11 December-10 January 2010.

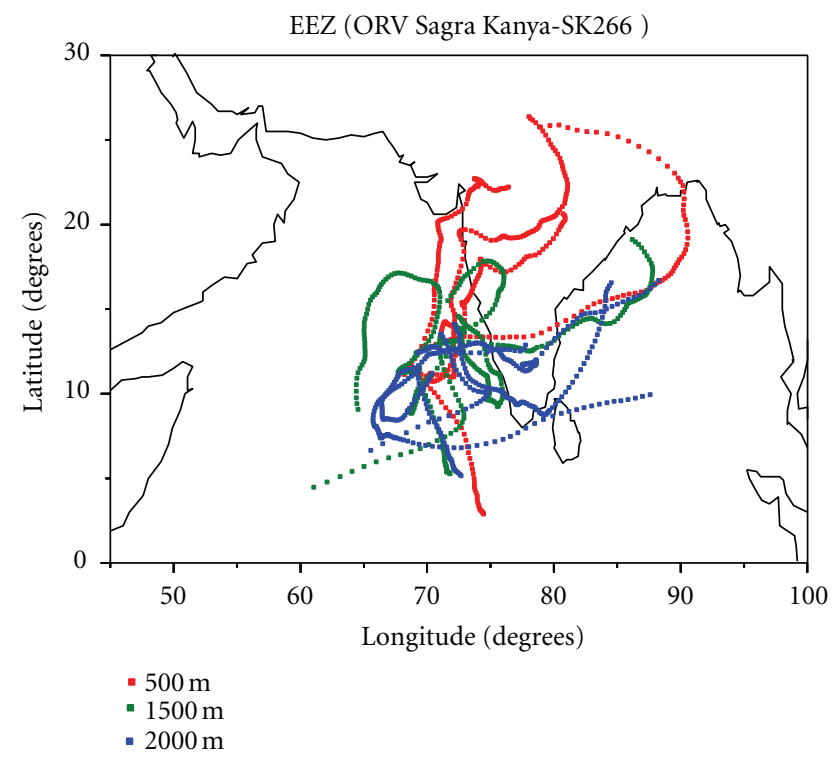

Figure 12: Seven-day air back trajectories for the days of aerosol measurements over the India's EEZ region at $500 \mathrm{~m}, 1500 \mathrm{~m}$, and $2000 \mathrm{~m}$ heights. The back trajectories are plotted at hourly interval. The symbols are shown at 24-h interval.

4.8. Relationship between AOT and Surface Meteorological Parameters. Meteorological instruments on the ship's deck provided information on the prevailing wind speed, direction, deck-level temperature $(\mathrm{T})$, pressure $(\mathrm{P})$, and relative humidity (RH). These data were continuously recorded at 3 hour interval during the cruise period and also at every hour during the Microtops observations when the ship was stabilized in position with the help of dynamic thrusters. The measurements of $\mathrm{T}$ and $\mathrm{RH}$ are made at the upper deck-level, about $10 \mathrm{~m}$ above the water level. The daily mean temperature, $\mathrm{RH}$, and wind speed in the India's EEZ region during the campaign period are plotted in Figure 13. The daily mean temperature was around $28-29.5^{\circ} \mathrm{C}$ or less during the India's EEZ which decreases to around $27^{\circ}-28^{\circ} \mathrm{C}$ on 27-29 December 2009 and 5 January 2010. RH is found to decrease from about $89 \%$ on 18 December 2009 and 6 January 2010 to less than $72 \%$. Thereafter, the RH increased and is found to be in the $80-89 \%$ range on $14,20,24,28$ December 2009. Daily mean RH increased to more than $80 \%$ on the days associated with fog. During the winter period over northern India, the low-level winds, in general, are calm, north/northeasterly, and arrive from the polluted northern hemisphere. During this period, we observed south-westerly winds at surface-level. RH was found to vary significantly during the day on foggy and hazy days. The daily average wind speed varied from 2.5 to $11 \mathrm{~m} / \mathrm{s}$, during the first week and last week of the campaign, that is, 13 December 2009 and 2 January 2010 the wind speed is low $(\sim 2.5 \mathrm{~m} / \mathrm{s})$, in the remaining time it varied from 4 to $19 \mathrm{~m} / \mathrm{s}$. The daily average AOT at $870 \mathrm{~nm}$ varied along with met parameters during the cruise period. It is evident from the figure that AOT increases with higher wind speed and vice versa, and AOT also increases with $\mathrm{RH}$, which confirms that the aerosols over the India's EEZ region are of hygroscopic nature and have affinity towards moisture. AOT variation with temperature is not very consistent as compared to those of $\mathrm{RH}$ and wind speed. Correlation coefficients of 0.6 and 0.58 were observed between AOT with wind speed and relative humidity, respectively.

4.9. Discrimination of Aerosol Types over India's EEZ. When attempting a realistic characterization of the aerosol properties, data of both AOT and Alpha have to be used [25] since they both strongly depend on wavelength. Thus scatter plots of AOT versus Alpha have been obtained to determine different aerosol types for a specific location through the determination of physically interpretable cluster regions in the diagram. Therefore, the detailed spectral information in different pairs of wavelengths can help in determining and discriminating between different aerosol types [26-28]. These AOT-Alpha patterns have been observed at several locations and for determining different aerosol types such as biomass smoke, anthropogenic aerosols, desert dust [2933]. In all the above studies, a wide range of values for low AOT at $500 \mathrm{~nm}$ were obtained, thus reflecting relatively clear continental conditions with strong variability in the dominant aerosol properties. Because of the poor correlation between AOT and Alpha, values of both quantities must be considered for a realistic analysis.

Figure 14 shows the density plot of AOT $500 \mathrm{~nm}$-Alpha $(380-1020 \mathrm{~nm})$ over the whole India's EEZ in the Arabian Sea. These contour maps were constructed in 0.1 steps for both AOT at $500 \mathrm{~nm}$ and Alpha (380-1020 nm) values. In the AOT $500 \mathrm{~nm}$-Alpha $(380-1020 \mathrm{~nm})$ plot rectangle areas denoted as urban-industrial (UI), clean-maritime (CM), desert-dust (DD), and mixed type (MT) aerosols, respectively, the boundaries of these areas concerning to the selected threshold values of AOT at $500 \mathrm{~nm}$ and Alpha. In such studies, the selection of the threshold values can be very important. In the present study, the AOT at $500 \mathrm{~nm}$ ranges from 0.14 to 1.0 , and the Alpha $(380-1020 \mathrm{~nm}$ ) from 0.4 to 1.7. The criterion for discriminating different aerosols, reported by Kalapureddy et al. [34], has been followed in the present study. For the same reason, the Alpha 


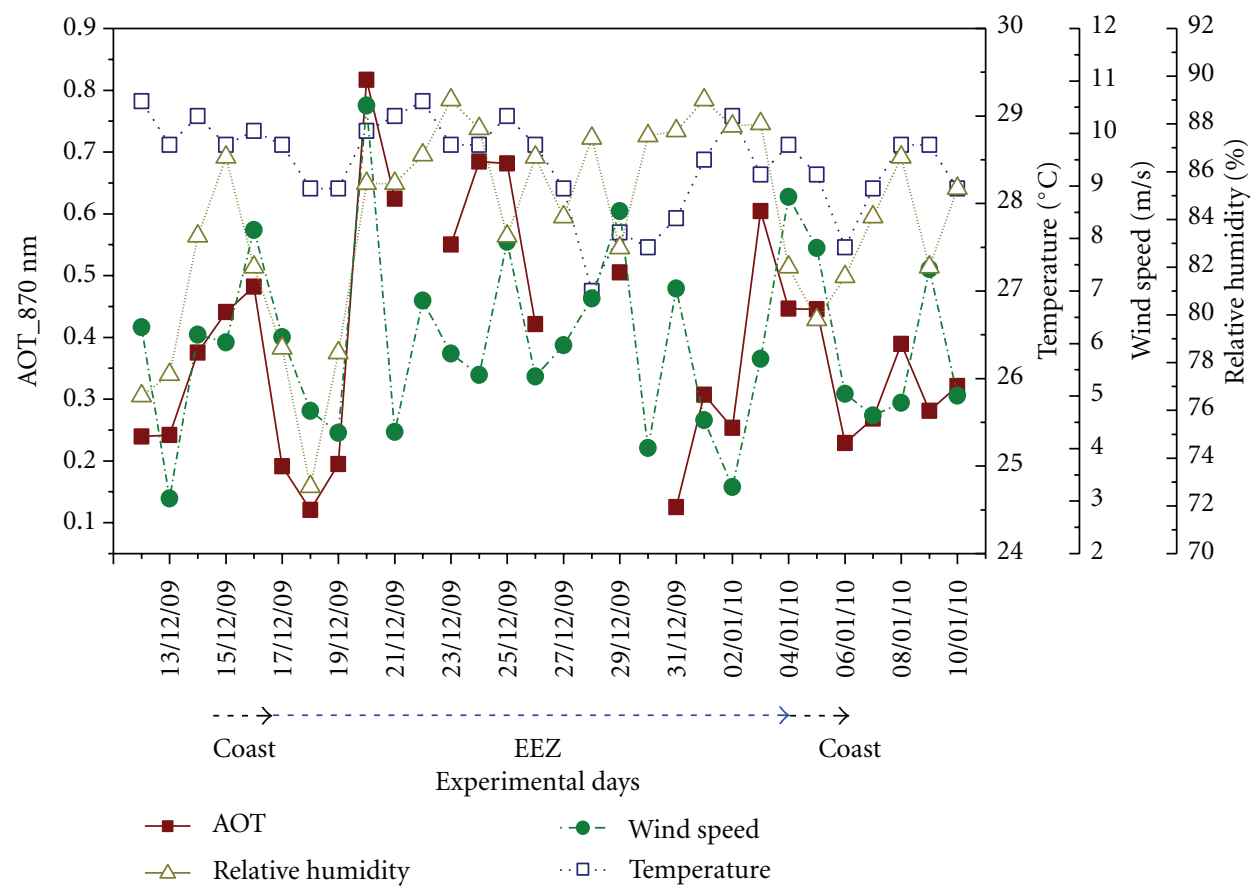

FIGURE 13: Variation of AOT with surface meteorological parameters.

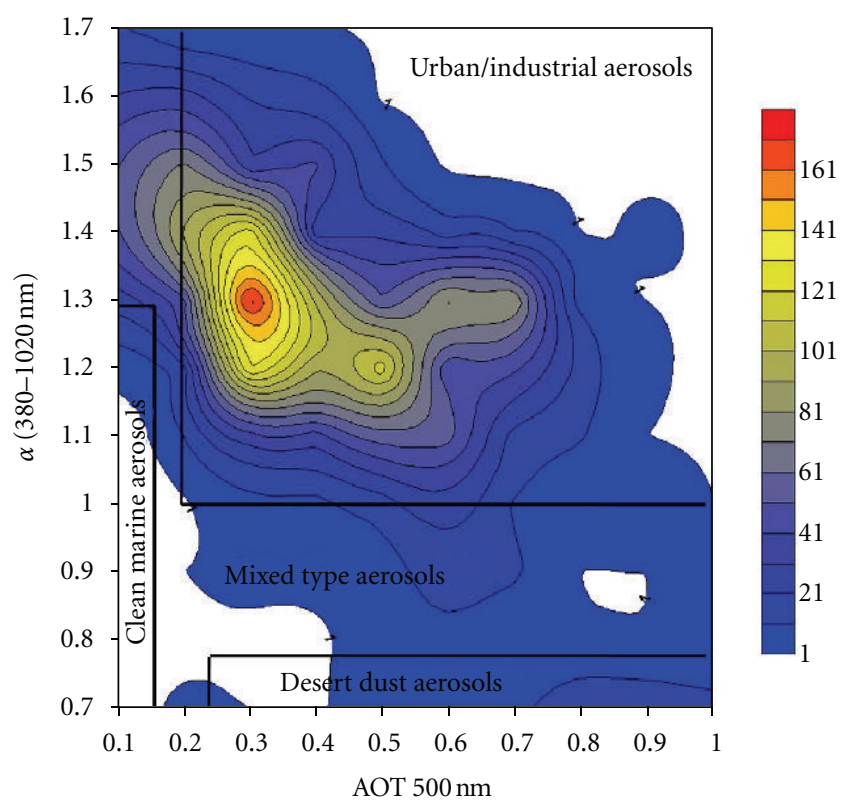

FIgUre 14: Contour density maps of the AOT $500 \mathrm{~nm}$ versus Alpha $380-1020 \mathrm{~nm}$ in the India's EEZ of Arabian Sea.

(380-1020 nm) threshold value for characterizing desertdust aerosols was taken slightly higher ( 0.7 against 0.5$)$ since the desert particles transported over oceanic regions can be mixed with the other aerosols and the larger particles are deposited near the source region; these processes lead to the increase of the Alpha values. Regarding the whole India's EEZ region!represented in Figure 14, a rather great scatter of data points is observed for low to moderate turbidity conditions, from which it is difficult to extract any useful information; only extreme values seem to be indicative of clear associations. Viewing the density plot of the whole India's EEZ, four areas of larger density are observed. However, the majority of the AOT $500 \mathrm{~nm}$ values lie between 0.15 and 0.6 . The Alpha $(380-1020 \mathrm{~nm})$ values are mainly depicted in the 0.4-1.7 interval. Previous studies over the AS region reveal the near similar AOT $500 \mathrm{~nm}$ (0.3) and Alpha (1.0) during premonsoon (March-May) season [35-38]. Moreover, the above studies while examining the synergy of observations (physical and chemical properties of aerosols) and models also explored the aerosol type information as the fractional contribution of different aerosol in the AOT which was about $10 \%$ by mineral dust and sea-salt contribution is around $20 \%$ and anthropogenic sources contribution is above $60 \%$ over AS around premonsoon season which are nearly comparable with the present results.

The four maximum density areas represent different aerosol types. Thus the absolute maximum density area, observed for the pair of AOT at $500 \mathrm{~nm}$, and Alpha (380$1020 \mathrm{~nm}$ ) is an indicator of moderate turbidity conditions dominated by UI aerosol type. Another maximum density area is depicted for (AOT at $500 \mathrm{~nm}$, Alpha $(380-1020 \mathrm{~nm}$ ) corresponds to MT aerosol, having larger fraction of coarsemode particles under more turbid conditions. The other two secondary maximum density areas are significantly lower, but quite characteristic of different aerosol types. Thus the (AOT at $500 \mathrm{~nm}$, Alpha $(380-1020 \mathrm{~nm}$ ) pair is characteristic of DD particles, while that AOT at $500 \mathrm{~nm}$ value of 0.5 and Alpha value of 1.1 is indicative of the transport of continental polluted plumes over AS. These different aerosol sources will 


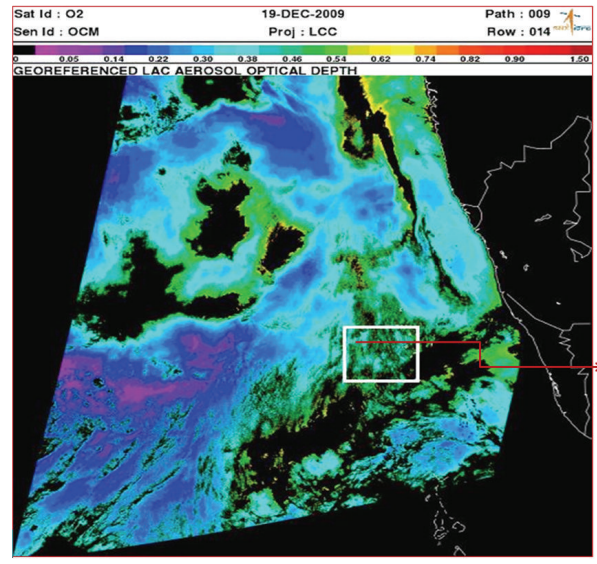

(a)

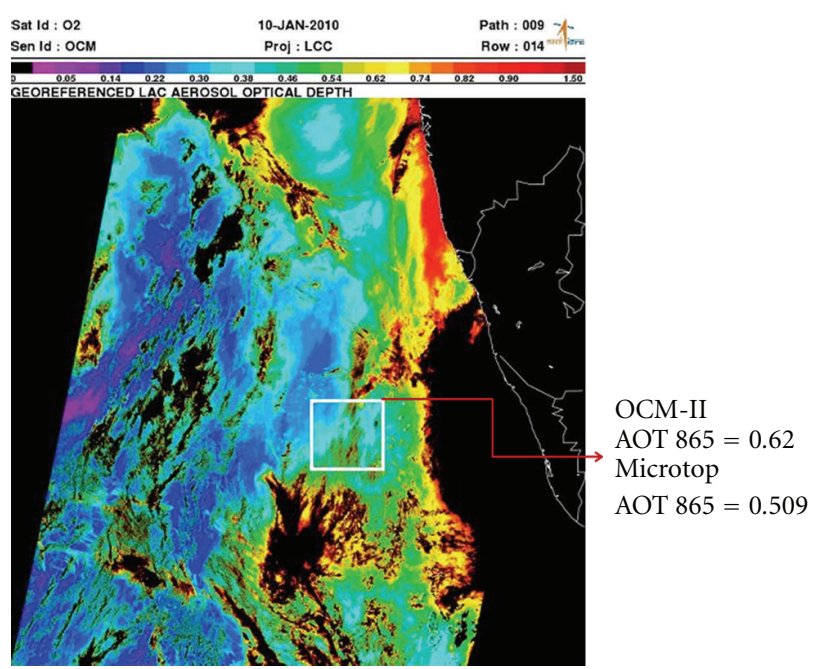

(b)

Figure 15: AOT-865 nm distribution as captured by OCEANSAT-2-OCM over the parts of the Arabian Sea.

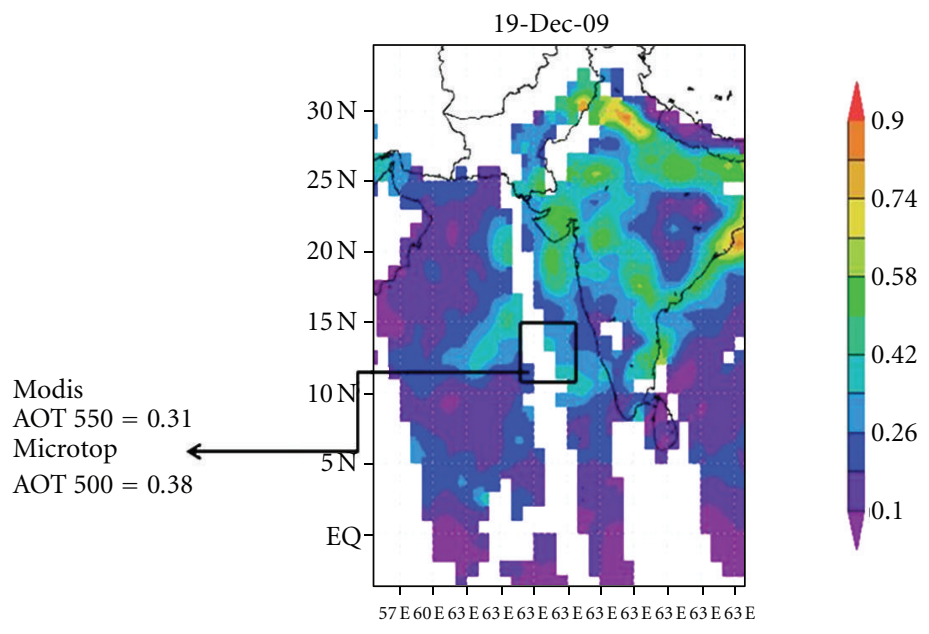

(a)

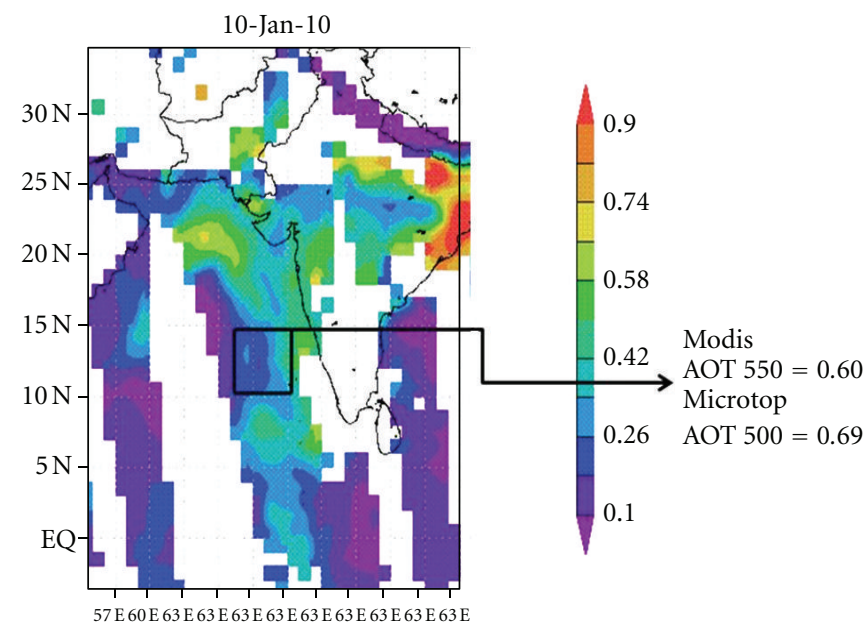

(b)

Figure 16: MODIS-Aqua AOT at $550 \mathrm{~nm}$ and Microtops AOT at $500 \mathrm{~nm}$ over the parts of the Arabian Sea. 
TABLE 1: Major specifications, features, and the geophysical products of OCEANSAT-II OCM.

\begin{tabular}{|c|c|c|}
\hline Parameter & Specification & \\
\hline Instantaneous Geometric Field-Of- View (IGFOV) at nominal altitude (m) & $360 \times 250$ & \\
\hline Swath $(\mathrm{km})$ & 1420 & \\
\hline Number of spectral bands & 8 & \\
\hline Spectral range $(\mathrm{nm})$ & $402-885$ & \\
\hline \multirow[t]{8}{*}{ Spectral bands (nm) } & B1: 404-424 & \\
\hline & B2: 431-451 & \\
\hline & B3: 476-496 & \\
\hline & B4: $500-520$ & \\
\hline & B5: 546-566 & \\
\hline & B6: $610-630$ & \\
\hline & B7: 725-755 & \\
\hline & B8: $845-885$ & \\
\hline Quantization bits & 12 & \\
\hline Along track steering & \pm 20 & \\
\hline \multirow[t]{2}{*}{ Data acquisition modes } & $\begin{array}{l}\text { Local area } \\
\text { coverage (LAC) } \\
\&\end{array}$ & \\
\hline & $\begin{array}{l}\text { Global area } \\
\text { coverage (GAC) }\end{array}$ & \\
\hline Geophysical parameter & Variable Range & Targeted error budget \\
\hline Aerosol Optical Thickness (AOT) over oceans at $865 \mathrm{~nm}$ & $0.0-1.0$ & $<20 \%$ \\
\hline
\end{tabular}

have direct effect on the wide range of Alpha (380-1020 nm) values, from 0.4 to 1.7 , especially for low AOT at $500 \mathrm{~nm}$ $(<0.15)$, suggesting a range of aerosol types from pure finemode pollutants to predominately coarse-mode particles. For higher values of AOT at $500 \mathrm{~nm}$, corresponding to dust conditions, Alpha is relatively low, a feature that compares well with that reported in the literature $[39,40]$. The properties of dust may also differ because of the variability of sources or the distance from the source region [41]. Thus, the detailed spectral information given by the determination of Alpha in different spectral bands helps us in determining and discriminating the aerosol types.

4.10. AOT Distribution as Seen from OCEANSAT-II and MODIS Satellites over the India's EEZ Region. The data products from OCM-2 are available at 360 meter spatial resolution for regional studies which are also called local area coverage (LAC) products. Table 1 provides the technical details of the OCEANSAT-II OCM instrument. The global area coverage (GAC) products are available at $4 \mathrm{~km}$ spatial resolution for global studies. The Level $1 \mathrm{~B}$ top of the atmosphere (TOA) radiance data from all the eight bands of OCM sensor is used along with ancillary information to generate various biogeophysical data products. The main geophysical products from OCM-2 are chlorophyll-a concentration, total suspended sediment concentration, vertical diffuse attenuation coefficient (Kd-90) at $490 \mathrm{~nm}$ and AOD at $865 \mathrm{~nm}$. These data products from OCM-2 can also be used for studying oceanic primary production, fisheries resources, global carbon cycle, spatial and temporal patterns of algal blooms, dynamics of coastal currents, physics of mixing and relationship between ocean physics and large scale patterns of productivity, land-ocean interaction in the coastal zone and sediment dynamics on regional as well as global scales. The availability of ocean-color data from OCM-2 opened new frontiers in remote sensing for open-sea as well as coastal regions on regional and global scales due to its relatively higher spatial resolution of around 360 meters. The obtained LAC data products during the cruise period are analyzed by using ENVISAT-II software at SAC, ISRO, Ahmedabad, India, and typical days were selected (19 December 2009 and 10 January 2010) as per the sky conditions are shown in Figures 15(a) and 15(b). Strong correlation was observed between Microtops and OCM-II data observed on these two days. The MODIS Aqua data products are also compared with the in-situ Microtops observations as shown in Figures 16(a) and 16(b). High correlation between AOTs deduced from MODIS and Microtops can be seen very clearly from the figure.

4.11. Aerosol Cluster during India's EEZ Campaign. Mean wind field during the SK-266 at different levels-1000 hPa and vorticity at $850 \mathrm{hPa}$ are shown in Figure 17. It can be noticed that winds in the northern and the north-western Arabian Sea in all the levels are conducive for the transport of coarse mineral dust from Arabian deserts and the arid regions of west Asia. On the other hand, in the case of southeastern Arabian Sea, even though the winds are favorable, 

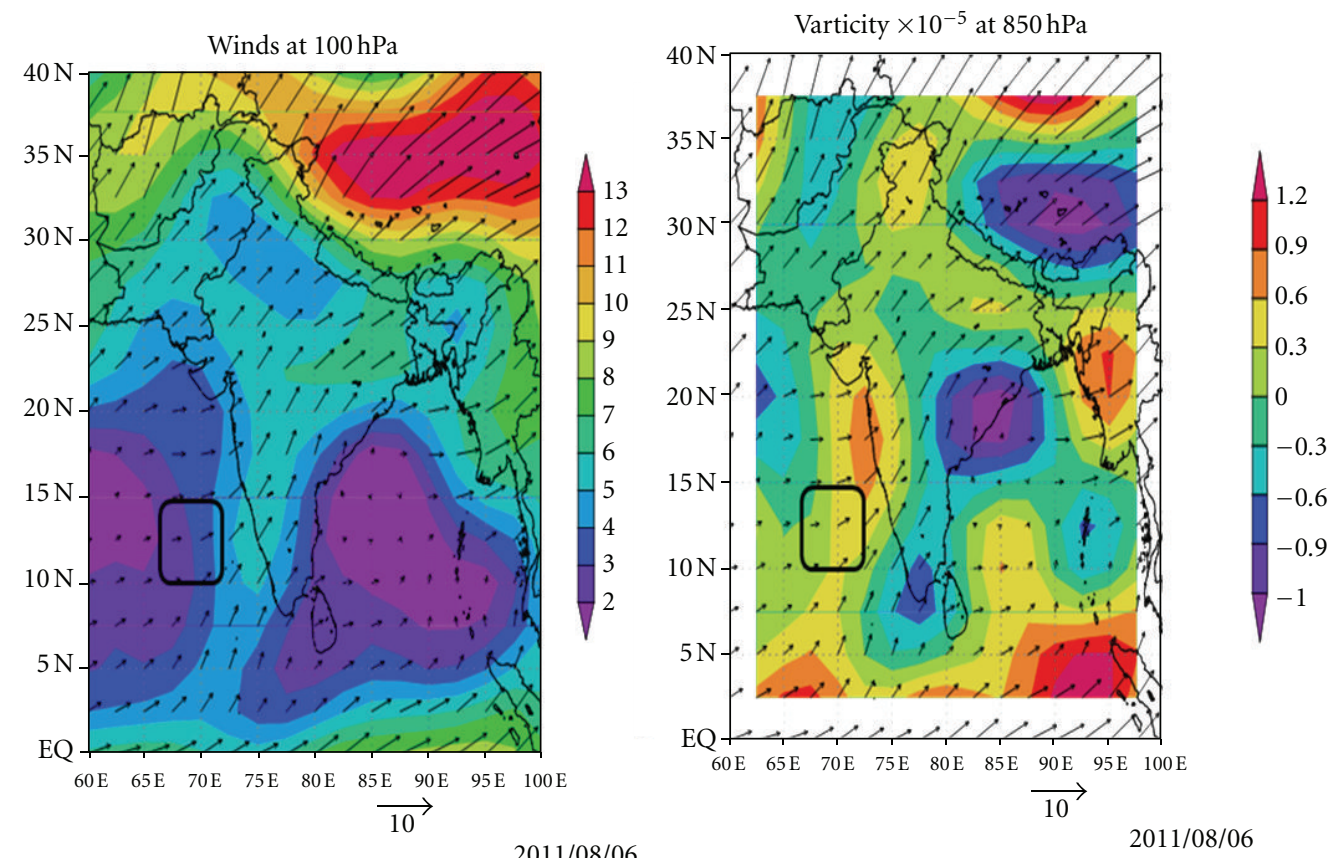

Figure 17: Spatial distribution of mean winds at $1000 \mathrm{hPa}$ and vorticity at $850 \mathrm{hPa}$ over the India's EEZ during the SK266.

dust particles transported from the AS would be lost on the way through gravitational settling since the distance involved is too large. Instead, the aerosols here will be mostly composed of particles from the urban and industrial centers along the west-coast collected by the lower altitude northerly winds $[34,42]$. A scrutiny of the wind field at lower altitudes, particularly, at the surface (responsible for marine aerosol production) does not show any major dayto-day variations about the mean behavior during the period of the event. Figure 17 shows the vorticity at $850 \mathrm{hPa}$ over the Arabian Sea. It was clearly seen that the anti-cyclonic circulation situated slightly west to the central peninsula was stronger on southern India and India's EEZ of the Arabian Sea. The southerly winds associated with this cyclonic flow are also very strong leading to the enhancement of wind convergence on these days of formation of the cluster of southern Indian peninsular (Figure 17). Therefore, it may be concluded that the short-term enhancement of the wind convergence at $850 \mathrm{hPa}$ has given rise to the accumulation of aerosols initiating the formation of the aerosol cluster. It would be interesting to note here that such elevated aerosol cluster formations over the Arabian Sea were detected during the Indian Ocean experiment (INDOEX) conducted in 1999 [43] which were attributed to upper level transport of continental aerosols from Arabia, eastern Pakistan, and the Thar desert where the frequency of dust storm activity is large during this period of the year [44-46]. In addition to dust particles, the initial composition of the aerosol cluster will contain some contribution of fine-mode aerosols from Indian subcontinent and coastal industries brought in by the cyclonic winds during the SK-266.

\section{Conclusions}

The Microtops observations carried out on-board Sagar Kanya in the India's EEZ of the Arabian Sea and concurrent OCM-II satellite data have been analyzed. The salient results of the study are highlighted below.

(i) Spectral variation of the AOT during the campaign shows significant influence of anthropogenic and natural activities on the pristine AOT $(\sim 0.14)$ and coastal AOT $(\sim 0.7)$, and sudden response of weather disturbance to AOT.

(ii) Lower values of Ozone due to photochemical reactions, and sudden increase of PWC due to formation of low pressure area in the India's EEZ.

(iii) Decrease in global solar flux with every 0.1 increase in $\mathrm{AOT}$, for SZA $<60^{\circ}$, over the India's EEZ of Arabian Sea was $20 \mathrm{~W} / \mathrm{m}^{2}$.

(iv) Long-range transport of air mass, consisting of north-eastern Indian land and south-eastern Sri Lankan and Arabian Sea aerosols play major role in the observed increase in fine-mode aerosol loading over the India's EEZ region.

(v) Over the observational site, UI aerosol density seems to be maximum and is followed by $\mathrm{CM}$ and $\mathrm{DD}$ type whereas MT type is found to be the least.

(vi) AOTs in the sensing region show strong correlation with wind speed and relative humidity. 
(vii) High correlation was observed between OCM-II level-2 product with in situ ground-based Microtops and MODIS satellite observations.

(viii) Spatial distributions of mean surface-level wind at $1000 \mathrm{hPa}$ and vorticity at $850 \mathrm{hPa}$ have shown southwesterly winds and strong convection during the study period, resulting in aerosol cluster formations in the India's EEZ.

\section{Acknowledgments}

The study reported here was carried out jointly by IITM, Pune and SAC-ISRO, Ahmedabad. The authors are grateful to the Editor and anonymous Reviewers for their constructive and insightful comments and suggestions on the original paper. One of the authors (CPS) is highly indebted to SAC for financial support in the form of Research Fellowship. Thanks are also due to Director, IITM, Pune, India for encouragement and infrastructure support.

\section{References}

[1] IPCC, "Report to IPCC from Scientific Assessment Group (WGI," in Intergovernmental Panel on Climate Change (IPCC), Cambridge University Press, Cambridge, UK, 1995.

[2] J. A. Coakley, R. D. Cess, and F. B. Yurevich, "The effect of tropospheric aerosols on the earth's radiation budget: a parameterization for climate models," Journal of the Atmospheric Sciences, vol. 40, no. 1, pp. 116-138, 1983.

[3] Y. J. Kaufman, D. Tanré, H. R. Gordon et al., "Passive remote sensing of tropospheric aerosol and atmospheric correction for the aerosol effect," Journal of Geophysical Research D, vol. 102, no. 14, pp. 16815-16830, 1997.

[4] I. Das and M. Mohan, "Detection of marine aerosols using ocean colour sensors," Mausam, vol. 54, pp. 327-334, 2003.

[5] R. J. Charlson, S. E. Schwartz, J. M. Hales et al., "Climate forcing by anthropogenic aerosols," Science, vol. 255, no. 5043, pp. 423-430, 1992.

[6] O. Dubovik, B. Holben, T. F. Eck et al., "Variability of absorption and optical properties of key aerosol types observed in worldwide locations," Journal of the Atmospheric Sciences, vol. 59, no. 3, pp. 590-608, 2002.

[7] C. Tomasi, V. Vitale, A. Lupi, A. Cacciari, S. Marani, and $\mathrm{U}$. Bonafe, "Marine and continental aerosol effects on the upwelling solar radiation flux in Southern Portugal during the ACE-2 experiment," Annals of Geophysics, vol. 46, no. 2, pp. 467-479, 2003.

[8] Intergovernmental Panel on Climate Change (IPCC), "Summary for policy makers," in Climate Change 2007: The Physical Science Basis. Contribution of Working Group I to the Fourth Assessment Report of the Intergovernmental Panel on Climate Change, S. Solomon, D. Qin, M. Manning et al., Eds., Cambridge University Press, Cambridge, UK, 2007.

[9] M. Rinaldi, S. Decesari, E. Finessi et al., "Primary and secondary organic marine aerosol and oceanic biological activity: recent results and new perspectives for future studies," Advances in Meteorology, vol. 2010, Article ID 310682, 10 pages, 2010.
[10] X. Liu, R. C. Easter, S. J. Ghan et al., "Toward a minimal representation of aerosols in climate models: description and evaluation in the Community Atmosphere Model CAM5," Geoscientific Model Development, vol. 5, pp. 709-739, 2012.

[11] G. W. Mann, K. S. Carslaw, D. A. Ridley et al., "Intercomparison of modal and sectional aerosol microphysics representations within the same 3-D global chemical transport model," Atmospheric Chemistry and Physics, vol. 12, pp. 4449 4476, 2012.

[12] P. C. S. Devara, S. K. Saha, P. E. Raj et al., "A four-year climatology of total column tropical urban aerosol, ozone and water vapour distributions over Pune, India," Journal of Aerosol and Air Quality Research, vol. 5, pp. 103-114, 2005.

[13] P. C. S. Devara, R. S. Maheskumar, P. E. Raj, K. K. Dani, and S. M. Sonbawne, "Some features of columnar aerosol optical depth, ozone and precipitable water content observed over land during the INDOEX-IFP99," Meteorologische Zeitschrift, vol. 10, no. 2, pp. 123-130, 2001.

[14] M. Morys, F. M. Mims, S. Hagerup et al., "Design, calibration, and performance of MICROTOPS II handheld ozone monitor and Sun photometer," Journal of Geophysical Research D, vol. 106, no. 13, pp. 14573-14582, 2001.

[15] C. Ichoku, R. Levy, Y. J. Kaufman et al., "Analysis of the performance characteristics of the five-channel Microtops II Sun photometer for measuring aerosol optical thickness and precipitable water vapor," Journal of Geophysical Research D, vol. 107, article 4179, 17 pages, 2002.

[16] K. S. Behera, Ed., Maritime Heritage of India, Aryan Books International, 1999.

[17] J. N. Porter, M. Miller, C. Pietras, and C. Motell, "Ship-based sun photometer measurements using microtops sun photometers," Journal of Atmospheric and Oceanic Technology, vol. 18, no. 5, pp. 765-774, 2001.

[18] K. D. Knobelspiesse, C. Pietras, and G. S. Fargion, "Sunpointing-error correction for sea deployment of the MICROTOPS II handheld sun photometer," Journal of Atmospheric and Oceanic Technology, vol. 20, pp. 767-771, 2003.

[19] A. Smirnov, B. N. Holben, I. Slutsker et al., "Maritime aerosol network as a component of aerosol robotic network," Journal of Geophysical Research D, vol. 114, no. 6, Article ID D06204, 10 pages, 2009.

[20] N. T. O'Neill, A. Ignatov, B. N. Holben, and T. F. Eck, “The lognormal distribution as a reference for reporting aerosol optical depth statistics; empirical tests using multi-year, multisite AERONET sunphotometer data," Geophysical Research Letters, vol. 27, no. 20, pp. 3333-3336, 2000.

[21] P. Chauhan, N. Sanwlani, and R. R. Navalgund, "Aerosol optical depth variability in the northeastern Arabian sea during winter monsoon: a study using in-situ and satellite measurements," Indian Journal of Marine Sciences, vol. 38, no. 4, pp. 390-396, 2009.

[22] M. C. R. Kalapureddy and P. C. S. Devara, "Pre-monsoon aerosol optical properties and spatial distribution over the Arabian Sea during 2006," Journal of Atmospheric Research, vol. 95, no. 2-3, pp. 186-196, 2010.

[23] T. F. Eck, B. N. Holben, J. S. Reid et al., "Wavelength dependence of the optical depth of biomass burning, urban, and desert dust aerosols," Journal of Geophysical Research D, vol. 104, no. 24, pp. 31333-31349, 1999.

[24] A. Jayaraman, D. Lubin, S. Ramachandran et al., "Direct observations of aerosol radiative forcing over the tropical Indian Ocean during the January-February 1996 preINDOEX cruise," Journal of Geophysical Research D, vol. 103, no. 12, pp. 13827-13836, 1998. 
[25] B. N. Holben, D. Tanré, A. Smirnov et al., "An emerging ground-based aerosol climatology: aerosol optical depth from AERONET," Journal of Geophysical Research D, vol. 106, no. 11, pp. 12067-12097, 2001.

[26] V. E. Cachorro, R. Vergaz, and A. M. De Frutos, "A quantitative comparison of $\alpha$ - $\AA$ turbidity parameter retrieved in different spectral ranges based on spectroradiometer solar radiation measurements," Atmospheric Environment, vol. 35, no. 30, pp. 5117-5124, 2001.

[27] G. Pace, A. di Sarra, D. Meloni, S. Piacentino, and P. Chamard, "Aerosol optical properties at Lampedusa (Central Mediterranean). 1. Influence of transport and identification of different aerosol types," Atmospheric Chemistry and Physics, vol. 6, no. 3, pp. 697-713, 2006.

[28] D. G. Kaskaoutis, H. D. Kambezidis, N. Hatzianastassiou, P. G. Kosmopoulos, and K. V. S. Badarinath, "Aerosol climatology: on the discrimination of aerosol types over four AERONET sites," Atmospheric Chemistry and Physics Discussions, vol. 7, no. 3, pp. 6357-6411, 2007.

[29] T. F. Eck, B. N. Holben, O. Dubovik et al., "Columnintegrated aerosol optical properties over the Maldives during the northeast monsoon for 1998-2000," Journal of Geophysical Research D, vol. 106, no. 22, pp. 28555-28566, 2001.

[30] T. F. Eck, B. N. Holben, D. E. Ward et al., "Characterization of the optical properties of biomass burning aerosols in Zambia during the 1997 ZIBBEE field campaign," Journal of Geophysical Research D, vol. 106, no. 4, pp. 3425-3448, 2001.

[31] M. Masmoudi, M. Chaabane, D. Tanré, P. Gouloup, L. Blarel, and F. Elleuch, "Spatial and temporal variability of aerosol: size distribution and optical properties," Journal of Atmospheric Research, vol. 66, no. 1-2, pp. 1-19, 2003.

[32] D. H. Kim, B. J. Sohn, T. Nakajima et al., "Aerosol optical properties over east Asia determined from ground-based sky radiation measurements," Journal of Geophysical Research D, vol. 109, no. 2, Article ID D02209, 18 pages, 2004.

[33] K. O. Ogunjobi, Z. He, K. W. Kim, and Y. J. Kim, "Aerosol optical depth during episodes of Asian dust storms and biomass burning at Kwangju, South Korea," Atmospheric Environment, vol. 38, no. 9, pp. 1313-1323, 2004.

[34] M. C. R. Kalapureddy, D. G. Kaskaoutis, P. E. Raj et al., "Identification of aerosol type over the Arabian Sea in the premonsoon season during the Integrated Campaign for Aerosols, Gases and Radiation Budget (ICARB)," Journal of Geophysical Research D, vol. 114, no. 17203, Article ID D17203, 12 pages, 2009.

[35] S. K. Satheesh, V. Ramanathan, X. Li-Jones et al., "A model for the natural and anthropogenic aerosols over the tropical Indian Ocean derived from Indian Ocean Experiment data," Journal of Geophysical Research D, vol. 104, no. 22, pp. 2742127440, 1999.

[36] K. K. Moorthy, A. Saha, B. S. N. Prasad, K. Niranjan, D. Jhurry, and P. S. Pillai, "Aerosol optical depths over peninsular India and adjoining oceans during the INDOEX campaigns: spatial, temporal, and spectral characteristics," Journal of Geophysical Research D, vol. 106, no. 22, pp. 28539-28554, 2001.

[37] V. Ramanathan, P. J. Crutzen, J. Lelieveld et al., "Indian Ocean Experiment: an integrated analysis of the climate forcing and effects of the great Indo-Asian haze," Journal of Geophysical Research D, vol. 106, no. 22, pp. 28371-28398, 2001.

[38] S. S. Babu, V. S. Nair, and K. K. Moorthy, "Seasonal changes in aerosol characteristics over Arabian Sea and their consequence on aerosol short-wave radiative forcing: results from ARMEX field campaign," Journal of Atmospheric and Solar-Terrestrial Physics, vol. 70, no. 5, pp. 820-834, 2008.
[39] A. Smirnov, B. N. Holben, O. Dubovik et al., "Atmospheric aerosol optical properties in the Persian Gulf," Journal of the Atmospheric Sciences, vol. 59, no. 3, pp. 620-634, 2002.

[40] K. O. Ogunjobi, Z. He, and C. Simmer, "Spectral aerosol optical properties from AERONET Sun-photometric measurements over West Africa," Journal of Atmospheric Research, vol. 88, no. 2, pp. 89-107, 2008.

[41] I. N. Sokolik, O. B. Toon, and R. W. Bergstrom, "Modeling the rediative characteristics of airborne mineral aerosols at infrared wavelengths," Journal of Geophysical Research D, vol. 103, no. 8, pp. 8813-8826, 1998.

[42] K. K. Moorthy, S. K. Satheesh, S. S. Babu, and C. B. S. Dutt, "Integrated Campaign for aerosols gases and Radiation Budget (ICARB): an overview," Journal of Earth System Science, vol. 117, no. 1, pp. 243-262, 2008.

[43] J.-F. Léon, P. Chazette, J. Pelon, F. Dulac, and H. Randriamiarisoa, "Aerosol direct radiative impact over the INDOEX area based on passive and active remote sensing," Journal of Geophysical Research D, vol. 107, no. 19, article 8006, 2002.

[44] E. J. Welton, K. J. Voss, P. K. Quinn et al., "Measurements of aerosol vertical profiles and optical properties during INDOEX 1999 using micropulse lidars," Journal of Geophysical Research D, vol. 107, no. 19, article 8019, 2002.

[45] B. Jha and T. N. Krishnamurthi, "Real-time meteorological reanalysis atlas during pre-INDOEX field phase-1998," Rep. 98-08, INDOEX Publ 20, Tallahassee, Department of Meteorology, Florida State University, 1998.

[46] K. Rajeev, V. Ramanathan, and J. Meywerk, "Regional aerosol distribution and its long-range transport over the Indian Ocean," Journal of Geophysical Research D, vol. 105, no. 2, pp. 2029-2043, 2000. 

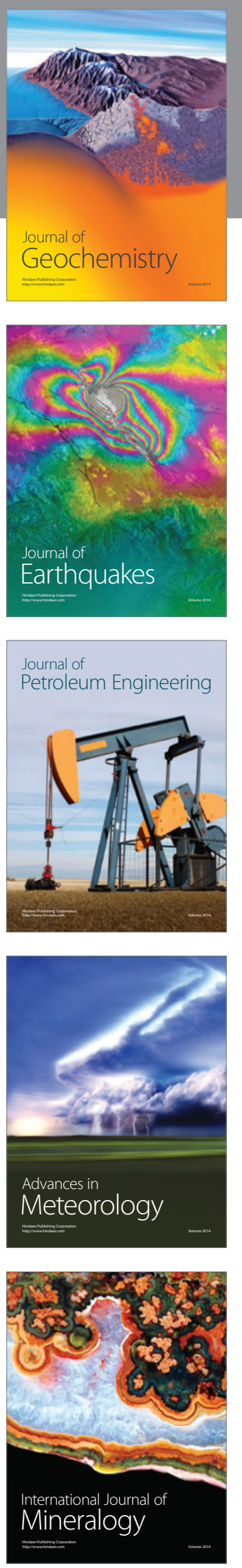
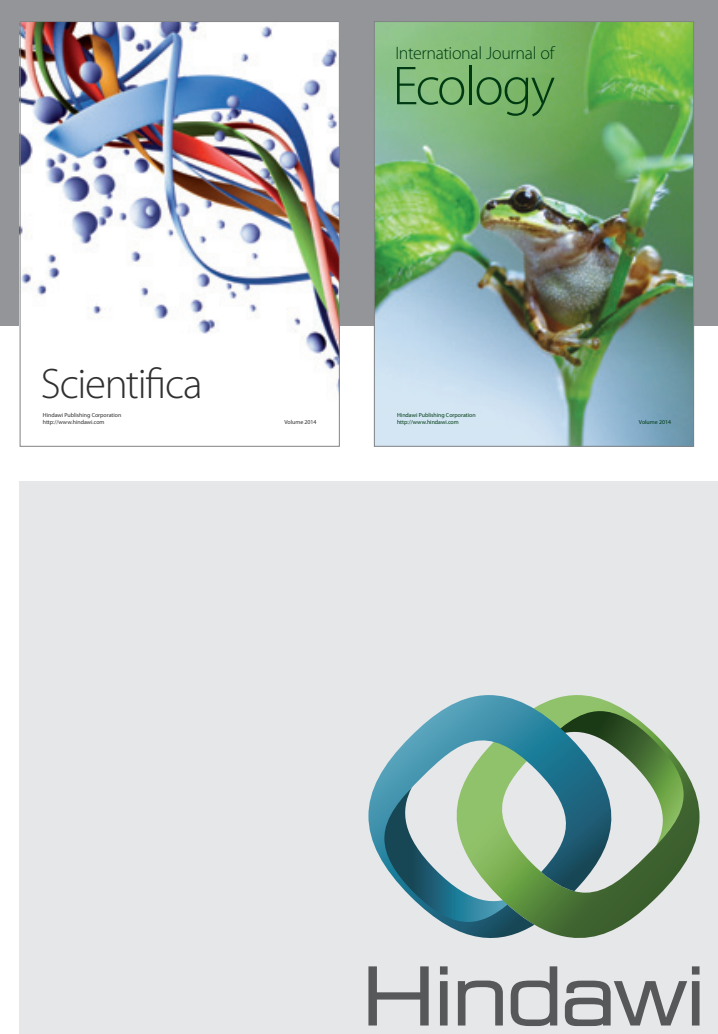

Submit your manuscripts at http://www.hindawi.com
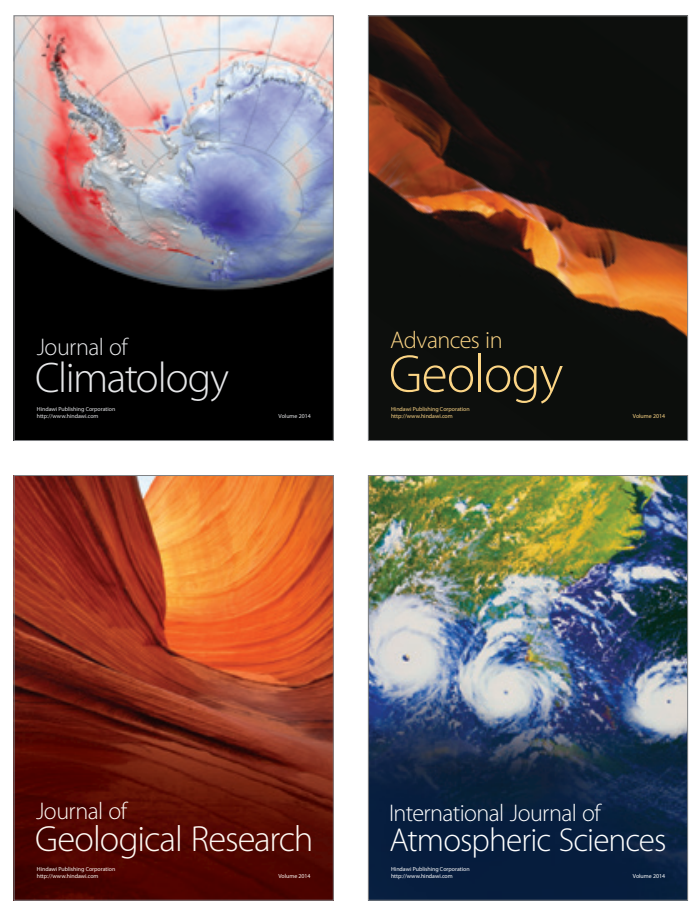
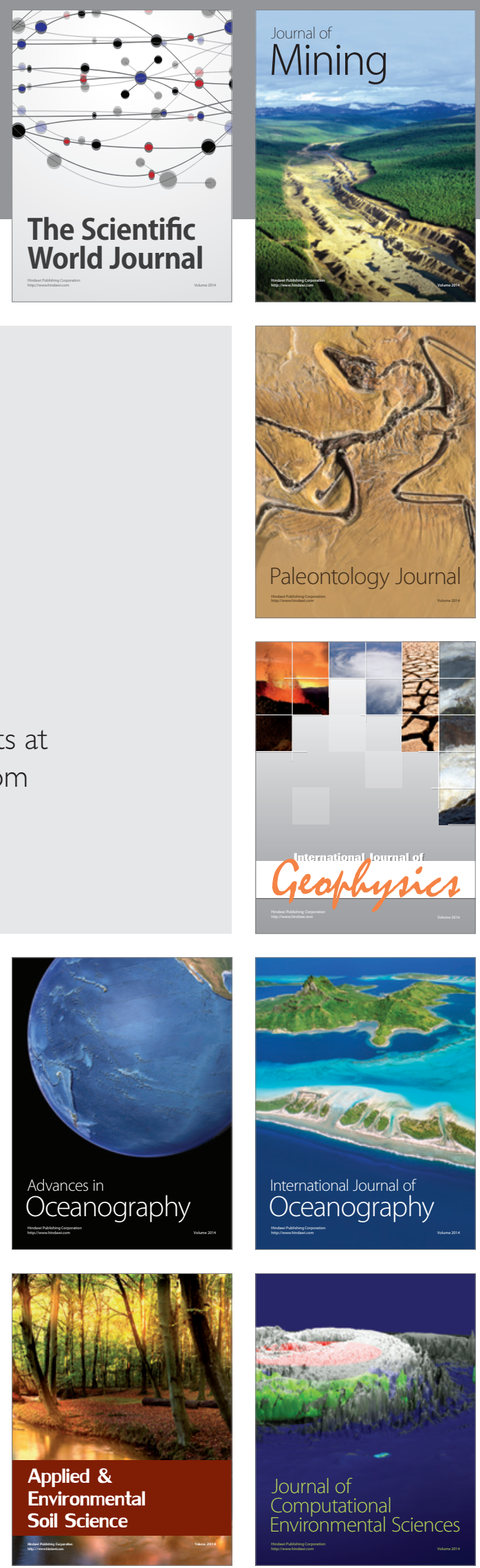